\title{
The Temporal Profile of 72-kDa Heat-Shock Protein Expression Following Global Ischemia
}

\author{
Roger P. Simon, Hiroyuki Cho, Ryder Gwinn, and Daniel H. Lowenstein \\ Department of Neurology, University of California at San Francisco, San Francisco, California 94143
}

\begin{abstract}
The potential role of the nonconstitutive 72-kDa heat-shock protein (HSP72) in selective neuronal vulnerability to ischemia was studied in rats subjected to graded global ischemia. Immunocytochemistry using a monoclonal antibody against HSP72 was performed on tissue collected after 24 hr of reperfusion. The appearance of HSP72 immunoreactivity correlated in a graded fashion with those regions known to be selectively vulnerable in ischemia. That is, HSP72 was induced in only hilar interneurons and CA1 pyramidal cells following brief ischemia. After intermediate durations of ischemia, HSP72 was expressed in the CA3 neurons and cortical layers 3 and 5 , and after the longest intervals, HSP72 appeared in dentate granule cells. Heat-shock protein expression preceded cell death (assessed with acid fuchsin staining) in all regions. This temporal profile suggests that the capability of neurons to express HSP72 is unlikely to account for selective vulnerability of different brain regions following ischemia; its role in neuroprotection during ischemic injury in vivo remains unknown.
\end{abstract}

Certain CNS neurons are selectively vulnerable to ischemia (Brierley and Graham, 1984), status epilepticus, and hypoglycemia (Meldrum and Corsellis, 1984). This vulnerability is especially marked in the pyramidal neurons of the hippocampus, neurons of the middle lamina of the cortical mantle, and nuclei of the lateral thalamus. The mechanism of the special vulnerability of these cells remains unknown, as does the cause of the delayed cell death of neurons of the CAl subsector of the hippocampus occurring 24-72 $\mathrm{hr}$ following ischemia in both the rat (Pulsinelli et al., 1982a) and the human (Petito et al., 1987). The original suggestion by Spielmeyer in 1925 of a specific vascular compromise affecting these neuronal groups has not been confirmed by modern studies (Pulsinelli et al., 1982b). The role of local factors, especially those of regional calcium accumulation (Deshpande et al., 1987; Andiné et al., 1988) and increased extracellular concentrations of excitatory amino acids (Benveniste et al., 1984), has received recent attention. Another potential mechanism underlying selective vulnerability may be related to the relative capacity of different regions of neurons to increase expression of specific proteins. It is well known that

\footnotetext{
Received July 2, 1990; revised Oct. 9, 1990; accepted Oct. 29, 1990.

We thank Drs. Kobert S. Sloviter and Frank Sharp for assistance in optimizing the conditions for immunocytochemistry and Dr. William Welch for providing monoclonal antibody raised against HSP72. This work was supported in part by NIH PPG NS 14543, NIH RO1 AA07032, and NIH KO8 NSO1424.

Correspondence should be addressed to Roger P. Simon, M.D., UCSF Neurology Service, Box 0870, San Francisco General Hospital, 1001 Potrero Avenue, 4M62, San Francisco, CA 94110.

Copyright (C) 1991 Society for Neuroscience $0270-6474 / 91 / 110881-09 \$ 03.00 / 0$
}

there are marked changes in protein synthesis following ischemia (Bodsch and Takahashi, 1983). Some of the most dramatic increases in expression are in the $70-\mathrm{kDa}$ heat-shock proteins. There is substantial evidence for a protective role of the highly inducible 72-kDa heat-shock protein (HSP72) in vitro during various cellular injury states (Welch, 1987), and a correlation between HSP72 expression and neuronal survival has recently been shown in vivo in a model of light-induced retinal injury (Barbe et al., 1988). To investigate the relationship between HSP72 expression and selective neuronal vulnerability in ischemia, we have studied the regional evolution of expression of HSP72 in the rat forebrain following graded global ischemia/ reperfusion and compared the patterns of HSP72 expression and neuronal injury.

\section{Materials and Methods}

Male Sprague-Dawley rats (325-350 gm) were anesthetized with chloral hydrate $(400 \mathrm{mg} / \mathrm{kg}$, i.p.), and the vertebral arteries were cauterized bilaterally. Rats were returned to their cages with access to food and water for $24 \mathrm{hr}$. The following day, animals were reanesthetized with chloral hydrate, the common carotid arteries were dissected free from the surrounding tissue, and global ischemia was produced by clamping of the arteries with microvascular clamps (Roboz 2 arterial clamps) for $2,3,4,5,6,8,10,15,20$, and $30 \mathrm{~min}$. Blood pressure and EEG were monitored, and animals having blood pressures below $80 \mathrm{~mm} \mathrm{Hg}$ or nonisoelectric EEGs during clamping were excluded from the study.

After $24 \mathrm{hr}$ of reperfusion, animals were reanesthetized with chloral hydrate $(400 \mathrm{mg} / \mathrm{kg}$ ) and killed by thoracotomy and transcardiac perfusion with $4 \%$ paraformaldehyde. Brains were removed and immersed in the same fixative for $24 \mathrm{hr}$ and then transferred to $0.1 \mathrm{M}$ Tris buffer $(\mathrm{pH}, 7.6)$. The brains were cut in $50-\mu \mathrm{m}$ sections on a vibratome and subsequently processed for immunocytochemistry and acid fuchsin staining. All sections were stained within 2 weeks after perfusion.

Immunocytochemistry. Tissue sections were washed in $0.1 \mathrm{M}$ Tris buffer 3 times for $5 \mathrm{~min}$ each, $1.0 \%$ hydrogen peroxide in Tris buffer for $30 \mathrm{~min}$, Tris buffer for $5 \mathrm{~min}$, Tris A $(0.1 \%$ Triton $\mathrm{X}$ in Tris buffer) for 15 min, Tris $\mathrm{B}(0.1 \%$ Triton $\mathrm{X}$ and $0.005 \% \mathrm{BSA}$ in Tris buffer) for $15 \mathrm{~min}, 10 \%$ normal horse serum in Tris $B$ for $1 \mathrm{hr}$, Tris $A$ for $15 \mathrm{~min}$, and Tris $B$ for $15 \mathrm{~min}$, then incubated in monoclonal antibody raised against HSP72 (kindly provided by William Welch) at 1:20,000 dilution in Tris $\mathrm{B}$ overnight at $5^{\circ} \mathrm{C}$.

The following day, the sections were washed in Tris A for $15 \mathrm{~min}$ and Tris $B$ for $15 \mathrm{~min}$, incubated in biotinylated horse anti-mouse IgG (Vector Labs, Burlingame, CA) at 1:200 dilution in Tris B for $45 \mathrm{~min}$, washed in Tris $A$ for $15 \mathrm{~min}$ and Tris $B$ for $15 \mathrm{~min}$, incubated in avidinbiotin-peroxidase (ABC kit from Vector Labs) at 1:1000 dilution in Tris $B$ for $1 \mathrm{hr}$, washed in Tris buffer 3 times for $5 \mathrm{~min}$, and then placed into a mixture of diaminobenzidine tetrahydrochloride (DAB; Sigma) at $0.5 \mathrm{mg} / \mathrm{ml}$, glucose oxidase (Sigma) at $3 \mathrm{mg} / \mathrm{ml}$, ammonium chloride (Sigma) at $200 \mathrm{mg} / \mathrm{ml}$, and D-(+)-glucose (Sigma) at $250 \mathrm{mg} / \mathrm{ml}$. Sections were reacted until optimal staining intensity was achieved, then washed in Tris, placed on slides, dried, dehydrated in $70 \%, 95 \%$, and $100 \%$ ethanol and xylene, and coverslipped using Permount (Fisher Scientific). Immunocytochemical negative control sections received identical treatment except for exposure to the primary antibody.

Acid fuchsin staining. Dried mounted sections were dipped sequen- 


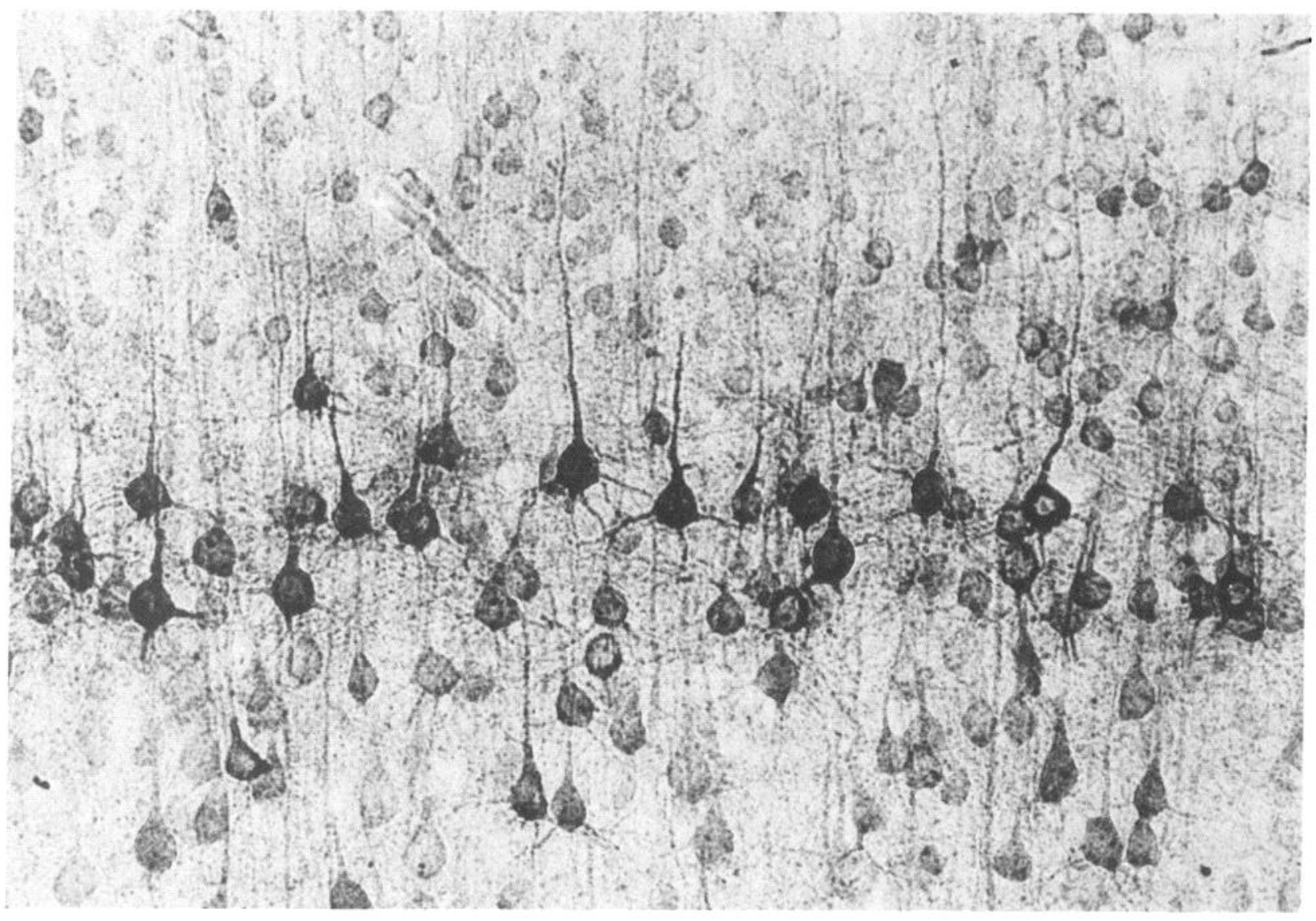

Figure 1. Section from lateral cortex $(200 \times)$ of rat subject to $15 \mathrm{~min}$ of ischemia and $24 \mathrm{hr}$ of reperfusion. The Golgi-like neuronal staining is notable (monoclonal antibody to HSP72 protein, courtesy of M. Welch).

tially in $\mathrm{H}_{2} \mathrm{O}, 70 \%, 95 \%$, and $100 \% \mathrm{EtOH}$, and xylene, then in $100 \%$, $95 \%$, and $70 \% \mathrm{EtOH}$ and $\mathrm{H}_{2} \mathrm{O}$ for 3 min each. Slides were then placed into a solution of acid fuchsin (Sigma) at $10 \mathrm{mg} / \mathrm{ml}$ and $0.1 \%$ glacial acetic acid in $\mathrm{H}_{2} \mathrm{O}$ for $2 \mathrm{~min}$; washed in $\mathrm{H}_{2} \mathrm{O}$ for $2 \mathrm{~min}$; placed into a solution of cresyl echt violet (Roboz) at $6 \mathrm{mg} / \mathrm{ml}, 1.16 \%$ glacial acetic acid, and sodium acetate at $27.2 \mathrm{mg} / \mathrm{ml}$ in $\mathrm{H}_{2} \mathrm{O}$ for $2 \mathrm{~min}$; washed in $\mathrm{H}_{2} \mathrm{O}$ for $5 \mathrm{~min}$; then dehydrated in $70 \%, 95 \%$, and $100 \% \mathrm{EtOH}$ for 1 min each and placed in xylene until coverslipping with Permount.

HSP72 expression was rated on 4 representative sections from each animal corresponding to $5.0-5.75,5.75-6.5,6.5-7.0$, and $8.5-9.5 \mathrm{~mm}$ anterior to the intraaural line with reference to levels in the Paxinos and Watson atlas (Paxinos and Watson, 1986). These levels represent the globus pallidus, anterior hypothalamus, thalamus, and caudate-putamen, respectively. A rating scale of $0-5$ was used, corresponding to the qualitative frequency of HSP72 expression: 0 , none; 1 , less than $20 \%$ of total cells; 2 , between $20 \%$ and $40 \%$ of cells; 3 , between $40 \%$ and $60 \%$ of cells; 4 , between $60 \%$ and $80 \%$ of cells; and 5 , over $80 \%$ of cells. An identical rating system was employed for the acid fuchsinstained material. Acid fuchsin-positive cells were defined as those staining bright red, clearly distinct from the pink staining of background and control material (Auer et al., 1984). Five animals were studied for each duration of ischemia. All ratings were performed in a blinded manner.

\section{Results}

\section{HSP72-like immunoreactivity}

The expression of HSP72 was seen as dense Golgi-like staining (Fig. 1) of neurons and some glia in the hippocampus, cortex, and thalamus. Within the dentate hilus, the shortest duration of ischemia ( $3 \mathrm{~min}$ ) produced HSP72 expression in small bipolar neurons in the hilar tip, or in hilar cells along the superior or inferior margins of the inner surface of the dentate granule cell layer (Fig. 2A). With slightly longer durations of ischemia, dense expression of HSP72 was seen throughout the hilus, involving neurons with mossy and bipolar cell morphology in the hilus proper and pyramidal neurons in the CA3-C region (Fig. $2 B$ ). With $15 \mathrm{~min}$ of ischemia in some animals, and $20 \mathrm{~min}$ in all animals, HSP72 expression within the hilar region was no longer seen, and some glial elements were recognizable.

In hippocampal pyramidal cell layers, ischemia of 4-min duration resulted in dense HSP72 expression (with Golgi-like staining of the neurons and their apical dendrites) throughout CA1 (Fig. 3B). With $10 \mathrm{~min}$ of ischemia, the CA1 staining involved fewer neurons and was considerably less dense than at earlier time points (Fig. $3 F$ ). With $20 \mathrm{~min}$, only a minority of cell bodies were stained, and no staining was seen in the apical dendrites. Following 20-30 min, infarction and necrosis were seen throughout CA1 (Fig. $3 H, I$ ).

In the CA3 region, HSP72 expression was first seen in some cells subjected to $4 \mathrm{~min}$ of ischemia (Fig. $3 B$ ) and was densely expressed following $8 \mathrm{~min}$ of ischemia (Fig. $3 E$ ). Expression in CA3 persisted in all later time points (Fig. $3 F-I$ ), but some

Figure 2. Dentate hilus $(100 \times)$ following $3 \mathrm{~min}(A)$ and $5 \mathrm{~min}(B)$ of ischemia stained with HSP72 monoclonal antibody. 

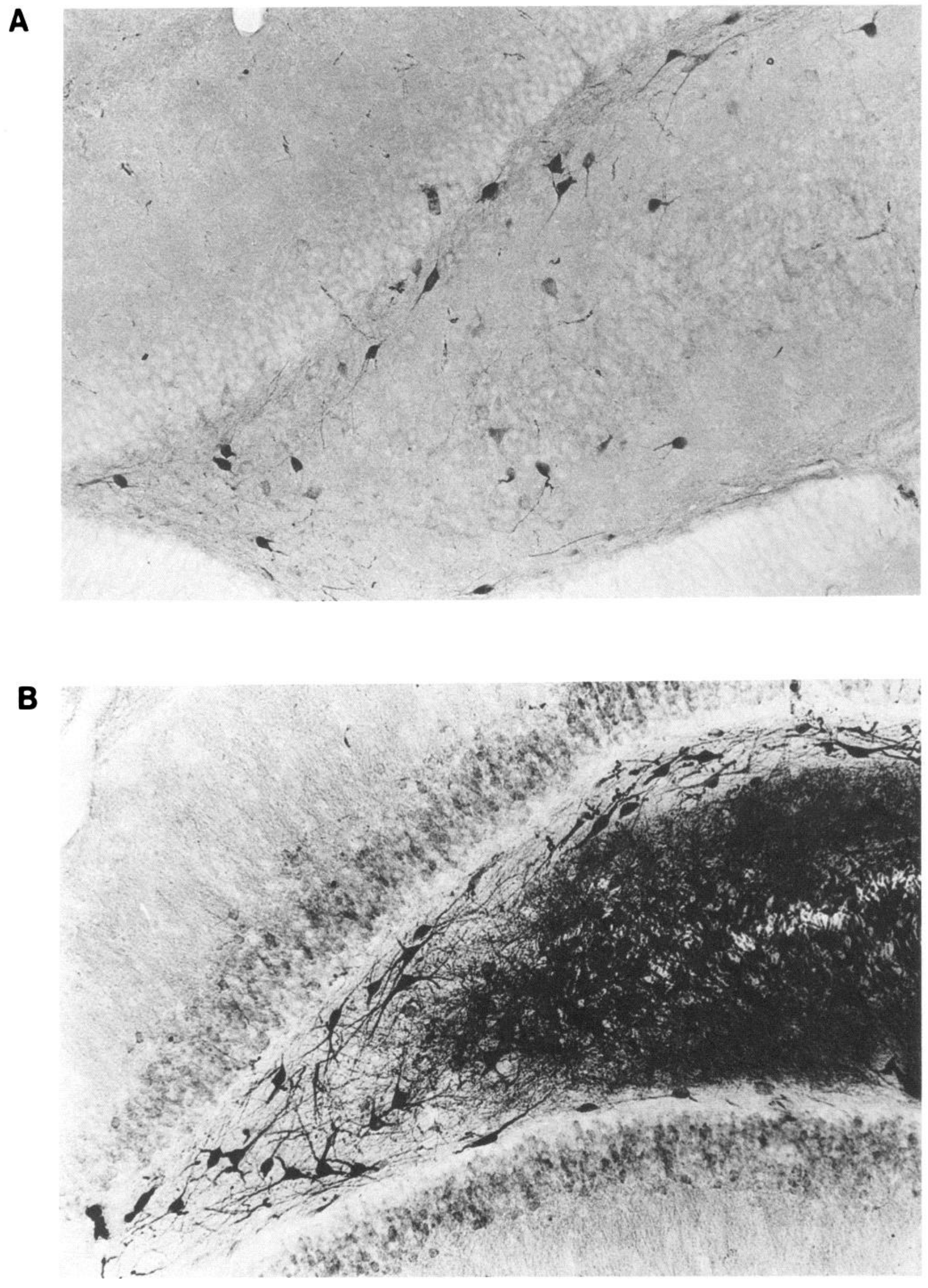

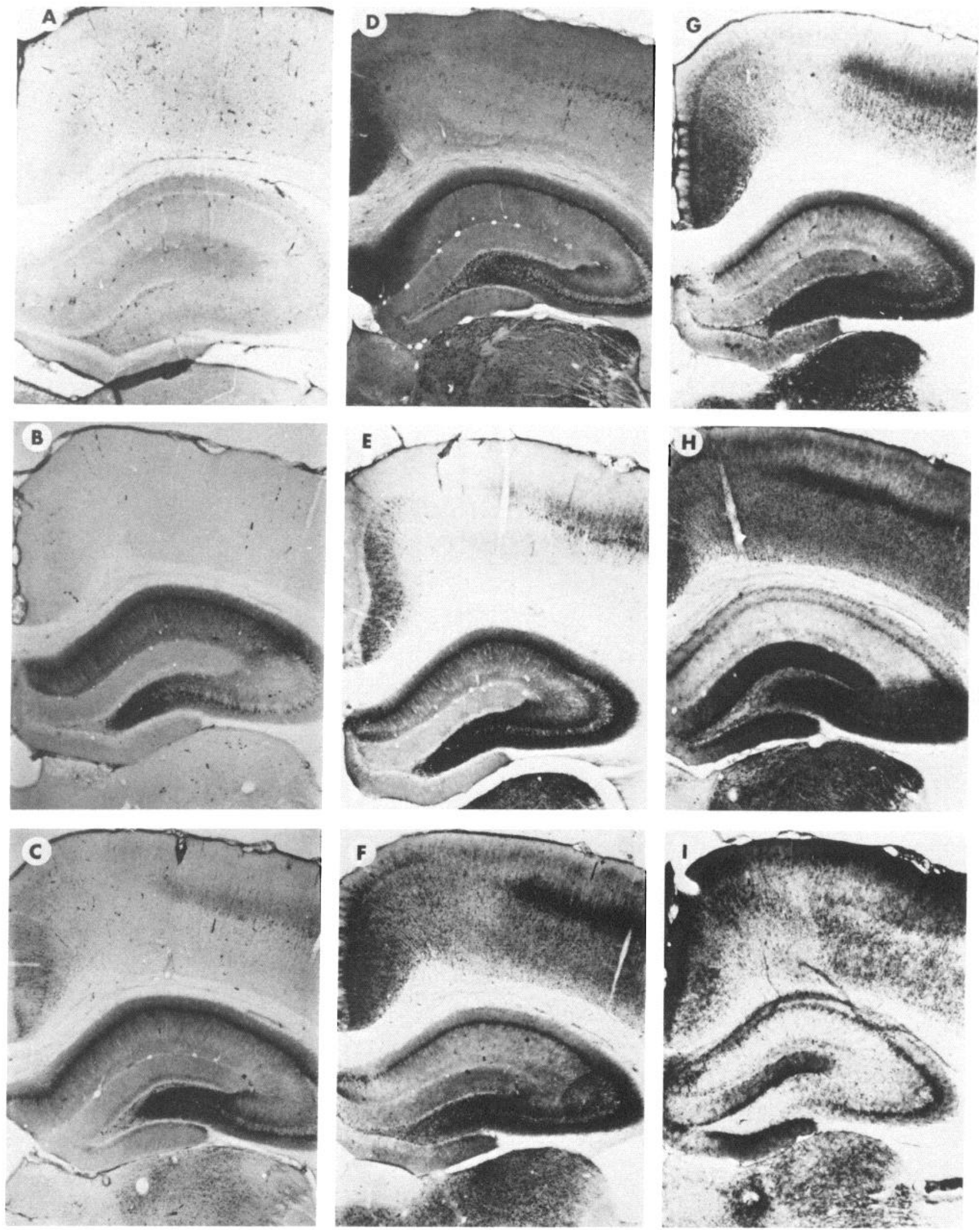

Figure 3. Representative sections through cortex and anterior hippocampus from rats killed $24 \mathrm{hr}$ following graded periods of global ischemia. $A, 3 \mathrm{~min} ; B, 4 \mathrm{~min} ; C, 5 \mathrm{~min} ; D, 6 \mathrm{~min} ; E, 8 \mathrm{~min} ; F, 10 \mathrm{~min} ; G, 15 \mathrm{~min} ; H, 20 \mathrm{~min} ; I, 30 \mathrm{~min}$. Sections were reacted with monoclonal antibody to HSP72 protein (courtesy of M. Welch). 


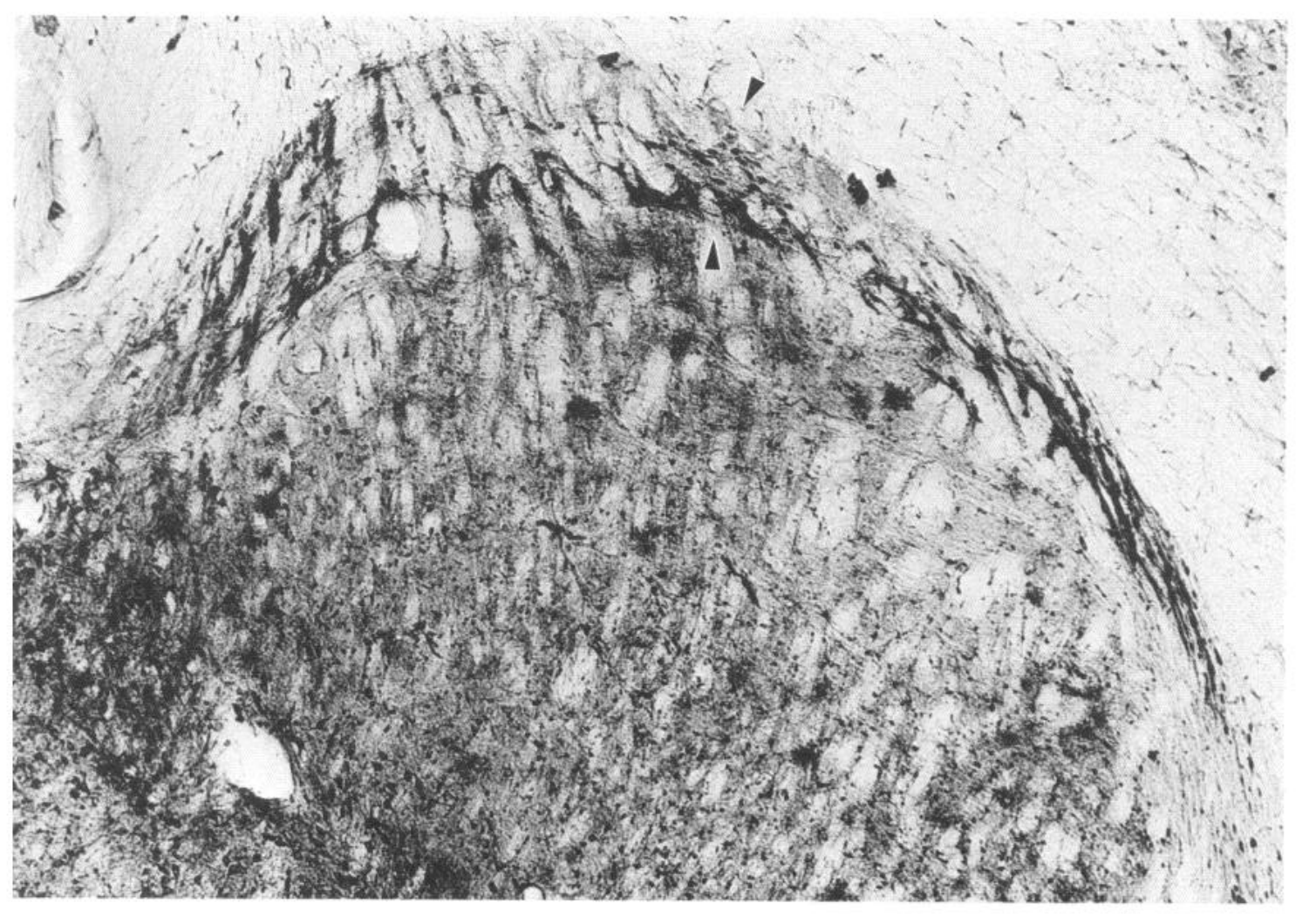

$\infty$

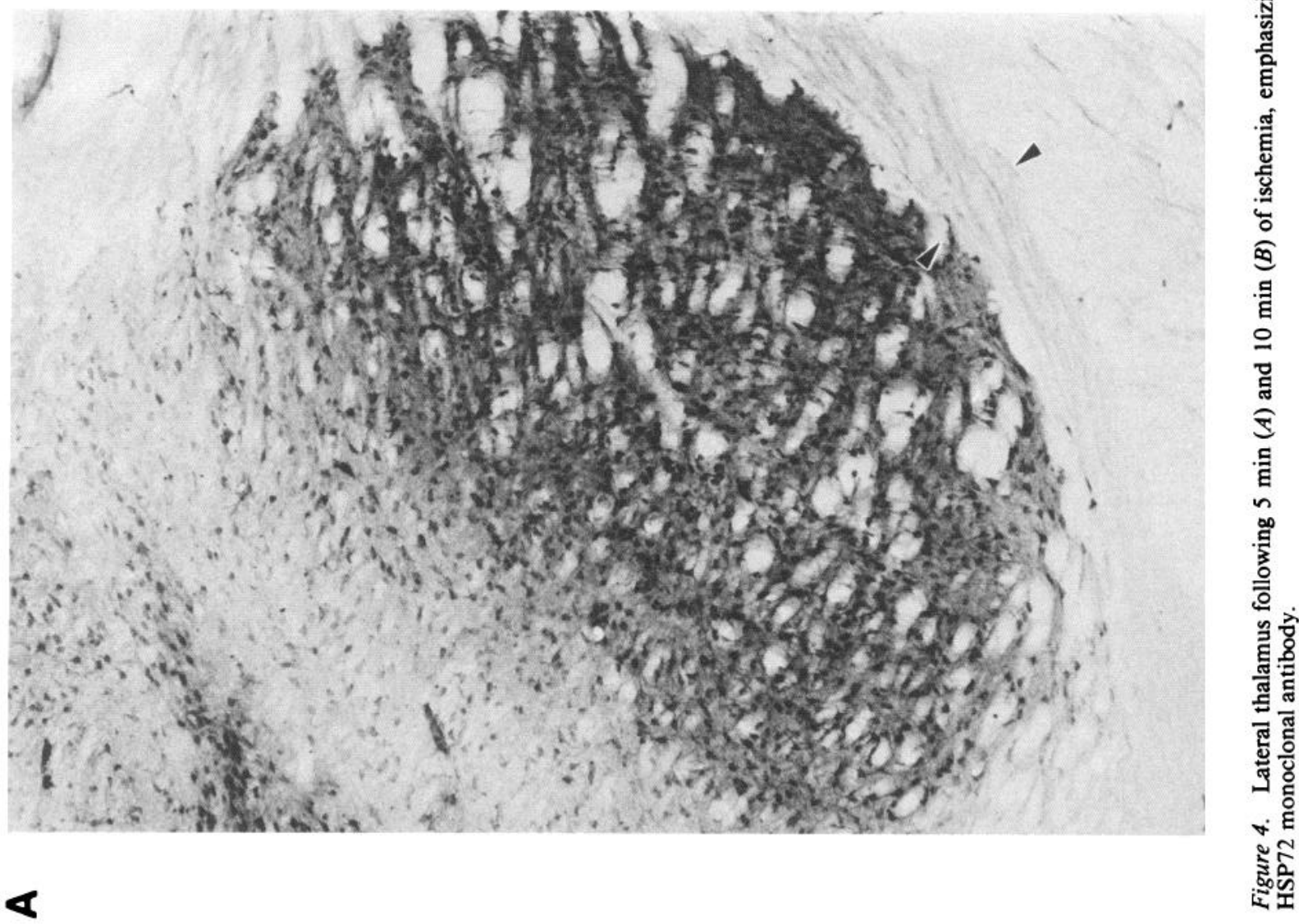


Figure 5. Quantitation of regional HSP72 expression and acid fuchsin staining $24 \mathrm{hr}$ following ischemia of $2-$ 30-min duration (shown as minutes, $m$ ), rated on a $0-5$ (minimal-maximal) scale as noted in Materials and Methods. Each time point represents observations on 5 animals. Solid line, HSP72; broken line, acid fuchsin, both $\pm \mathrm{SD}$.
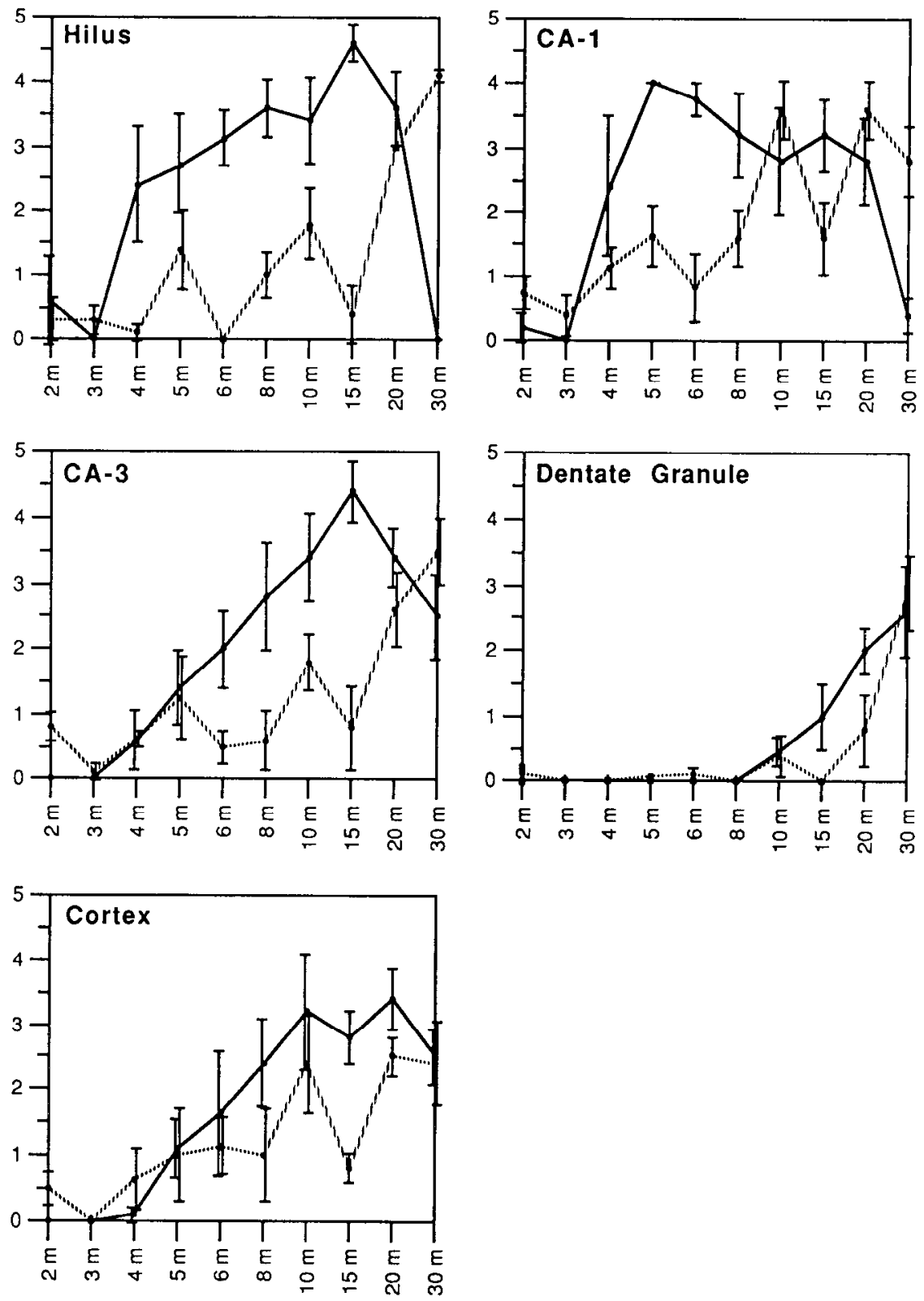

animals had cell loss in this region following $30 \mathrm{~min}$ of ischemia (Fig. 3I).

Faint expression was seen in the dentate granule cells following $10 \mathrm{~min}$ of ischemia (Fig. $3 F$ ). The dorsal and ventral blades were equally affected. This pattern persisted until the 20-30min durations of ischemia (Fig. $3 H, I$ ), when expression of the protein was dense in the dentate granule cells and their dendrites. This pattern was often associated with pyknosis and necrosis of the pyramidal neurons in CA3c.

The ventral posterior medial nuclei (VPM) and ventral posterior lateral thalamic nuclei (VPL) expressed HSP72 after 4 min of ischemia and were prominent at $5 \mathrm{~min}$ (Fig. $4 A$ ). The reticular nucleus appeared spared at these time points. Dense expression was seen in these nuclei following ischemia of $6-\mathrm{min}$ duration. With $8 \mathrm{~min}$, more dorsal and medial thalamic nuclei were involved, corresponding mainly to the ventral dorsal thalamic nucleus and the medial dorsal thalamic nuclei. After 10 min, there was prominent expression throughout the thalamus, but there was a marked attenuation of expression in VPL and VPM (Fig. 4B). The reticular nuclei densely expressed the protein at this time. With 15 and $20 \mathrm{~min}$, glial clements were prominent in VPL and VPM. In addition, following $20 \mathrm{~min}$ of ischemia, prominent glial cells were seen throughout the tuber cinereum.

Within the cortical mantle, the first changes in HSP72 expression were observed in large pyramidal neurons in layers 3 and 5 throughout the middle cerebral artery (MCA) distribution following as little as $3 \mathrm{~min}$ of ischemia (not illustrated). With 5 min of ischemia, the anterior cingulate region demonstrated expression of the protein within the pyramidal neurons in addition to a laminar array in the MCA distribution of primary somatosensory cortex (Fig. 3C).

Frontal area 1 (primary motor cortex) did not show expression of HSP72 through $8 \mathrm{~min}$ of ischemia (Fig. $3 C-E$ ). The pattern of cingulate and parietal laminar expression of the protein persisted through the 10-min time point of ischemia (Fig. 3F). After 


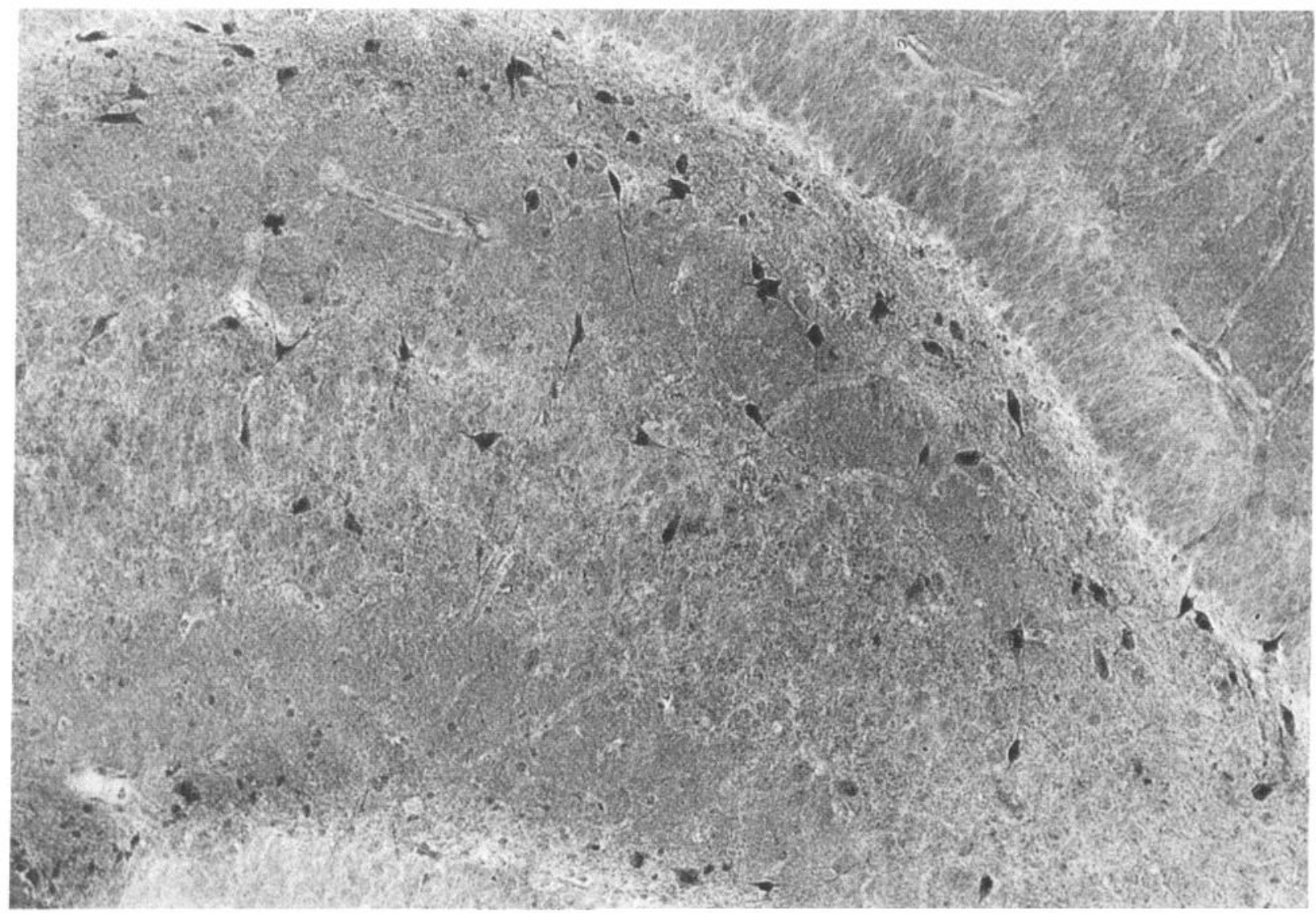

Figure 6. Dentate hilus $(100 \times)$ stained with acid fuchsin and photographed with red-free light after 6 min of ischemia with $24 \mathrm{hr}$ of reperfusion.

$20 \mathrm{~min}$, the laminar expression of the protein was seen throughout the cortical mantle to include primary motor cortex (Fig. $3 H$ ). At this time, expression in the cingulate gyrus was extremely dense in the granular cells of layer 2 . After $30 \mathrm{~min}$ of ischemia, the distinct laminar pattern in the cortex was no longer prominent, with HSP72 expression seen throughout the cortex, but the density and the number of cells expressing the protein had diminished (Fig. 3I).

\section{Acid fuchsin staining}

Acid fuchsin-positive cells were found in all regions expressing HSP72, and their appearance was in the the same graded temporal pattern as that seen with HSP72 (Fig. 5). Acid fuchsinpositive cells were found earliest within the dentate hilus (Fig. 6), next in CA1 and the medial thalamus, then in CA3 the cortical mantel and was seen in the dentate granule cells only following the longest durations of ischemia. In each brain region examined, HSP72 expression always preceded acid fuchsin staining.

\section{Discussion}

The precise mechanisms that result in neuronal cell death during ischemia are complex and incompletely understood (Raichle, 1983; Siesjö, 1984). Recent evidence has supported a central role for endogenous excitatory amino acid neurotransmitters as a major source of the metabolic perturbations that lead to cell death following ischemia, prolonged seizures, and hypoglycemia (Rothman and Olney, 1986; Meldrum et al., 1987; Choi, 1988).
However, cell excitation and excitatory amino acids may not be the complete explanation for selective vulnerability (Auer et al., 1988). For example, there is little change in extracellular glutamate during prolonged epileptic seizures (Lehmann et al., 1985), and during hypoglycemia, aspartate increases while glutamate decreases (Agardh et al., 1978). Additionally, excitatory receptor density does not accurately predict susceptibility to neuronal death among hippocampal pyramidal neurons during spontaneous seizures in the gerbil (Mouritzen Dam et al., 1981).

In this study, we have examined another factor, other than cell excitation, that might be responsible for the selective vulnerability to ischemia of some CNS neurons: the ability to induce stress-related or heat-shock proteins. The expression of the major inducible 70-kDa heat-shock protein has been proposed to confer protection from various insults in vitro (Welch, 1987). By using a model of ischemia that results in highly reproducible and graded amounts of injury, we were able to investigate the temporal correlation between HSP72 expression and ischemic cell injury.

The most important finding in this study was that HSP72 expression was seen throughout those cell groups (cortical mantel, hippocampus, thalamus) known to be selectively vulnerable to ischemis. Furthermore, among these vulnerable neuronal populations, there was a marked variability in the duration of ischemia that would provoke a stress protein response: least in the hilar interneurons, lateral thalamic nuclei, and CA1 subsector of the hippocampus; intermediate in the CA3 hippocampal subsector and the cortical mantle; and greatest in the dentate 
granule cells. Thus, the graded response of stress protein expression mirrors the graded vulnerability of these cell groups to ischemia. Significantly, regional HSP72 expression preceded staining with acid fuchsin, a dye that is considered to stain dead cells (those unable to exclude an acid dye; Auer et al., 1984). These observations are compatible with the idea that stress protein induction occurs when the tolerance for ischemia is reached. Accordingly, those cells most susceptible to ischemia, for example, hilar interneurons and CAl pyramidal cells, express the protein after brief periods of ischemia, while resistant regions, for example, dentate granule cells, only express the protein after sustained durations of ischemia.

In the study of Vass et al. (1988), only a few cells expressing HSP72 were found in the CAl sector of the hippocampus in the gerbil following $10 \mathrm{~min}$ of global ischemia with 4-96 hr of reperfusion. On the other hand, HSP72 was expressed prominently in the CA3 regions. The possibility that the cell death of the CAl neurons was related to an inability of these cells to express HSP72 70 was suggested. The present study shows robust expression of HSP72 in CA1 pyramidal neurons occurring within the first $24 \mathrm{hr}$ following periods of ischemia more brief than those of Vass et al. (1988; Figs. $3 B-G, 5$ ). With increasing durations of ischemia, HSP72 expression in CA1 is no longer seen (Fig. $3 H, I$ ). It remains to be determined whether this decrease in HSP72 expression is related to changes at the level of transcription, translation, or subsequent protein processing. What is clear, however, is that the vulnerability of CA1 neurons is not due to an inability to express HSP72.

HSP72 production produces tolerance to multiple cell toxins (e.g., heavy metals, ethanol, calcium ionophores) in in vitro studies (for review, see Welch, 1987), and a direct role in protection has been shown (Riabowol et al., 1988). In the CNS, increased expression of HSP72 has been demonstrated with trauma (Brown et al., 1989), hyperthermia (Barbe et al., 1988), ischemia (Nowak, 1985), and seizures (Lowenstein et al., 1990). An increase in the synthesis of HSP72 has been correlated with a decrease in photoreceptor susceptibility of light damage in the rat (Barbe et al., 1988). Although the precise mechanism underlying the protective effect of these stress proteins is incompletely understood, a role for HSP72s in the translocation of proteins across membranes has been suggested (Chirico et al., 1988; Beckmann et al., 1990). A function of the HSP72s may be to provide protection for critical precursor proteins prior to their final assembly or incorporation into cell membranes. This protection could preclude "inappropriate" protein-protein interactions, such as those of proteases and lipases, which are active in cells following ischcmia (Sicsjö, 1984). The rcgional expression of HSP72s and other proteins, such as GAP-43, a growth cone protein found in the human brain, could be associated with the well-known regional vulnerability of the brain to ischemia ( $\mathrm{Ng}$ et al., 1988). The data presented here demonstrate both a regional and a temporal association between selective neuronal vulnerability in ischemia and the expression of a major stress protein, which may be a putative marker of impending cell death. Whether HSP72 plays a protective role in attenuating ischemic neuronal injury in vivo remains to be shown.

Although HSP72 expression is temporally related to the vulnerability of CNS neurons to ischemia, it is unlikely that HSP72 expression explains selective vulnerability. If this were the case, HSP72 expression should be seen preferentially in cells resistant to ischemia (e.g., astroglia) and not in vulnerable cells (e.g., hippocampal pyramidal ncurons). Our data present essentially the opposite picture. Nonetheless, these findings do not exclude the possibility that induction of HSP72 prior to ischemia will reduce subsequent cell injury (Chopp et al., 1989).

\section{References}

Agardh C-D, Folbergrová J, Siesjö BK (1978) Cerebral metabolic changes in profound insulin-induced hypoglycemia, and in the recovery period following glucose administration. $J$ Neurochem 31 : $1135-1142$.

Andiné P, Jacobsen I, Hagberg H (1988) Calcium uptake evoked by electrical stimulation is enhanced postischemically and precedes delayed neuronal death in CAl of rat hippocampus: involvement of $N$-methyl-D-aspartate receptors. J Cereb Blood Flow Metab 8:799807.

Auer RN, Siesjö BK (1988) Biological differences between ischemia, hypoglycemia and epilepsy. Ann Neurol 24:699-707.

Auer RN, Wieloch T, Olsson Y, Siesjö BK (1984) The distribution of hypoglycemic brain damage. Acta Neuropathol 64:177-191.

Barbe MF, Tytell M, Gower DJ, Welch WJ (1988) Hyperthermia protects against light damage in the rat retina. Science 241:18171820.

Beckmann RP, Mizzen LA, Welch WJ (1990) Interaction of HSP70 with newly synthesized proteins: implications for protein folding and assembly. Science 248:850-854.

Benveniste H, Drejer J, Schousboe A, Diemer NH (1984) Elevation of the extracellular concentrations of glutamate and aspartate in rat hippocampus during transient cerebral ischemia monitored by intracerebral microdialysis. J Neurochem 43:1369-1374.

Bodsch W, Takahashi K (1983) Selective neuronal vulnerability to cerebral protein- and RNA-synthesis in the hippocampus of the gerbil brain. In: Cerebral ischemia (Bes A, Braquet P, Paoletti R, Siesjö BK, eds), pp 197-208. New York: Elsevier.

Bodsch W, Takahashi K, Barbier A, Ophoff BG, Hossmann K-A (1985) Cerebral protein synthesis and ischemia. Brain Res 63:197-210.

Brierley JB, Graham DI (1984) Hypoxia and vascular disorders of the central nervous system. In: Greenfield's neuropathology (Adams JH, Corsellis JAN, Duchen W, eds), pp 125-208. New York: Wiley.

Brown IR, Rush S, Ivy GO (1989) Induction of heat shock gene at the site of tissue injury in the rat brain. Neuron 2:1559-1564.

Choi DW (1988) Glutamate neurotoxicity and diseases of the nervous system. Neuron 1:623-634.

Chopp M, Tidwell BS, Lee YJ, Knight R, Helpern JA, Welch KMA (1989) Reduction of hyperthermic ischemic acidosis by a conditioning event in cats. Stroke 20:1357-1360.

Chirico WJ, Waters MG, Blobel G (1988) $70 \mathrm{~K}$ heat shock related proteins stimulate protein translocation into microsomes. Nature 332 805-810

Deshpande JK, Siesjö BK, Wieloch T (1987) Calcium accumulation and neuronal damage in the rat hippocampus following cerebral ischemia. J Cereb Blood Flow Metab 7:89-95.

Lehmann A, Hagberg H, Jacobson I, Hamberger A (1985) Effects of status epilepticus on extracellular amino acids in the hippocampus. Brain Res 359:147-151.

Lowenstein DH, Gonzalez M, Simon RP, Sharp F (1990) The pattern of $72 \mathrm{kDa}$ heat shock protein-like immunoreactivity in the rat brain following fluorothyl-induced status epilepticus. Brain Res 531:173182.

Meldrum BS, Corsellis JAN (1984) Epilepsy. In: Greenfield's neuropathology (Adams JH, Corsellis JAN, Duchen W, eds), pp 921-950. New York: Wiley.

Meldrum BS, Evans MC, Swan JH, Simon RP (1987) Protection against hypoxic/ischaemic brain damage with excitatory amino acid antagonists. Med Biol 65:153-157.

Mouritzen Dam A, Bajorek JC, Lomax P (1981) Hippocampal neuron density and seizures in the Mongolian gerbil. Epilepsia 22:667-674.

Ng S-C, Monte SM, Conboy GL, Karns LR, Fishman MC (1988) Cloning of human GAP-43: growth association and ischemic resurgence. Neuron 1:133-139.

Nowak TS (1985) Synthesis of a stress protein following transient ischemia in the gerbil. J Neurochem 45:1635-1641.

Paxinos G, Watson C (1986) The rat brain in stereotaxic coordinates. San Diego: Academic.

Petito CK, Feldmann E, Pulsinelli WA, Plum F (1987) Delayed hippocampal damage in humans following cardiorespiratory arrest. Neurology $37: 1281-1286$. 
Pulsinelli WA, Brierley JB, Plum F (1982a) Temporal profile of neuronal damage in a model of transient forebrain ischemia. Ann Neurol 11:491-498.

Pulsinelli WA, Levy DE, Duffy TE (1982b) Regional cerebral blood flow and glucose metabolism following transient forebrain ischemia. Ann Neurol 11:499-509.

Raichle ME (1983) The pathophysiology of brain ischemia. Ann Neurol 3:2-10.

Riabowol KT, Mizzen LA, Welch WJ (1988) Heat shock is lethal to fibroblasts microinjected with antibodies against HSP72 70. Science 242:433-436.

Rothman SM, Olney JW (1986) Glutamate and the pathophysiology of hypoxic-ischemic brain damage. Ann Neurol 19:105-111.
Siesjö BK (1984) Cerebral circulation and metabolism. J Neurosurg 60:883-908.

Spielmeyer W (1925) Zur pathogenese örtlich elektiven Gehirnveränderungen. Zeitschrift für die gesamte. Neurol Psychiatr 99:756-776.

Vass K, Welch WJ, Nowak TS Jr (1988) Localization of 70-kDa stress protein induction in gerbil brain after ischemia. Acta Neuropathol 77:128-135.

Welch WJ (1987) The mammalian heat shock (or stress) response: a cellular defense mechanism. In: Immunobiology of proteins and peptides, IV (Atassi, ed), pp 287-304. New York: Plenum. 